\title{
Heritage Tourism Marketing: Status, Prospects and Barriers
}

\author{
Mahamudul Hasan ${ }^{1}$, Md. Imrul Jobaid ${ }^{2}$ \\ ${ }^{1}$ Lecturer, Department of Marketing, Faculty of Business, Bangladesh University of Business and Technology \\ (BUBT), Postal Address: Room No. 509, Bangladesh University of Business and Technology (BUBT) \\ ${ }^{2}$ Lecturer, Department of Marketing, Faculty of Business Studies, Jagannath University, 9-10, Chittaranjon \\ Avenue, Dhaka-1100, Bangladesh.
}

\begin{abstract}
Heritage tourism marketing plays a significant role to attract tourists in heritage destinations. Bangladesh is endowed with historical and archaeological sites. The country has all the potential to be an important heritage destination in the world. Well-planned marketing of these heritage destinations is a primary requirement to attract both foreign and domestic tourists. There are some barriers which can impede successful heritage tourism marketing in Bangladesh. Lack of coordination among stakeholders, insufficient funding and providing less importance to the needs of the tourists can obstruct successful heritage tourism marketing. Developing creative promotional program, coordination among relevant stakeholders, conservation and protection of heritage sites and active participation of both private and public sector are necessary to implement heritage tourism marketing in Bangladesh.
\end{abstract}

Keywords: Bangladesh, Tourism, Heritage Tourism, Heritage tourism marketing, Heritage tourism products.

\section{Introduction}

Visiting historical and archaeological sites is a popular tourist activity among tourists in the world. Heritage sites are attractive destinations for visit in almost every country for that reason the importance of heritage tourism is increasing day by day. Heritage tourism can be defined as visiting historical and archaeological sites for the purpose of acquiring knowledge or entertainment. Bangladesh is a small South Asian country that has a rich culture, history and archaeological sites which are very important heritage destinations in the world. This country has a great potential to become an important heritage destination in the world. Wellplanned marketing program is essential to attract tourists in heritage destinations. Many developed and developing countries have successfully used marketing concepts and tools to attract heritage tourists in their countries. But heritage tourism marketing has not been given proper attention in Bangladesh and for that reason the number of heritage tourists is much less in this country than the neighboring countries such as Srilanka, Maldives, India and Bhutan. This study investigates the status, potential and barriers of heritage tourism marketing in Bangladesh.

\subsection{Literature review}

Tourism is a social, cultural and economic phenomenon which entails the movement of people to countries or places outside their usual environment for personal or business/professional purposes [1] (Understanding tourism: basic glossary, 2014). Tourism is a leisure activity which involves a discretional use of time and money and recreation is often the main purpose for participation in tourism[2] (Ghosh, 2001). Tourism is emerged from the movement of people to and their stay in various destinations. There are two basic elements in tourism, such as the journey to the destination and the stay. In short, tourism means the business of providing information, transportation, accommodation and other services to travelers [2] (Ghosh, 2001). Tourism industry includes all the socio-economic activities that are directly or indirectly involved in providing services to the tourists [3] (Dabour, 2003). Tourism can be classified into several distinct categories. They would include holiday travel, visiting friends and relatives (VFR), business travel, health treatment, shopping, conference, incentive travel, official mission, education, sport and others travel [4] (Malaysia Tourism Promotion Board, 2004). Tourism marketing is an integrated effort to satisfy tourists by making available to them the best possible services. It is a device to transform the potential tourists into actual tourists. It is the safest way to generate demand and expand market[5] (Shamsuddoha, 2005). As an important element of Marketing Mix, promotion plays the vital role in tourism marketing as like any products and services. Tourists want to know about the attractions and facilities of a particular destination. They also desire to know about other related information of his or her visit to make the tour safe, secured and enjoyable [6] ( Ali and Parvin, 2010). When tourists plan for a trip, they look for available information, services and facilities, tour operators, things to see and do, safety and security, accommodation and transportation and others necessary information about the location from different sources. Internet is the mostly used media for getting information in this modern age. Besides surfing on internet, people also visit travel agents, tour operator and other organizations to get reliable 
and realistic information. Here stands the term of tourism marketing. All these above tools which are used for the publicity of tourism destinations are known as tourism marketing [7](Weiermair \& Mathies 2004, 97-100.). Heritage is the things of value which are inherited. If the value is personal, we speak of family or personal heritage; if the value is communal or national, we speak of our heritage[8] (Edgell, 2006).

Heritage places are those which help an understanding of the past; enrich the present and which will be of value to the future generations. For the places of archeological and architectural values, it is the people and activities that form the cultural heritage[9] ( Ahmed, 2006).

Heritage tourism is defined by the National Trust for Historic Preservation (NTHP) as"traveling to experience the places, artifacts, and activities that authentically represent the stories and people of the past and present. It includes cultural, historic and natural resources" [10] (National Trust for Historic Preservation, 2008). Heritage tourism uses assets - historic, cultural and natural resources — that already exist. Rather than creating and building attractions, destinations look to the past for a sustainable future. Indeed these assets need preservation and often restoration or interpretation, but the foundation for creating a dynamic travel experience lives on in the stories and structures of the past[11] (Hargrove, 2002).

Definitions and descriptions of what constitutes heritage tourism are far from consistent. [12](Silberberg, 1995) uses a definition from the Economic Planning Group of Canada for cultural tourism: "visits by persons from outside the host community motivated wholly or in part by interest in the historical, artistic, and scientific or lifestyle/heritage offerings of the community, region, group or institution".

Marketing is the critical element of heritage. Heritage tourism is a highly competitive and marketoriented business, and many heritage sites around the world place great emphasis on attracting and maintaining a viable market share. The importance of marketing heritage tourism is attached to understanding the nature of demand for heritage so that product development and promotional strategies may be devised in accordance with the needs and expectations of visitors .In heritage management our customers are our visitors[13] ( Gitera, 2008).

\subsection{Objectives of the Study}

The main objective of this study is to investigate the status, prospects and barriers of heritage tourism marketing in Bangladesh. The specific objectives are:

1. To identify important heritage tourism products in Bangladesh.

2. To develop a SWOT analysis of heritage tourism industry in Bangladesh.

3. To find out the present status of heritage tourism marketing in Bangladesh.

4. To find out barriers of heritage tourism marketing in Bangladesh.

5. To investigate the potential impact of heritage tourism marketing in Bangladesh.

6. To propose a heritage tourism marketing framework for Bangladesh.

7. To suggest recommendations for effective heritage tourism marketing in Bangladesh.

\subsection{Methodology of the Study}

To achieve the objectives of the study both the primary and secondary information have been collected. Secondary information sources are journals, newspapers, websites and reports of different tourism related organizations. The number of literatures on the present status and promotional aspects of heritage tourism is not satisfactory for that reason interviews have been taken form 100 respondents. The respondents are tourists who visit different heritage destinations in Bangladesh and the people who are associated with tourism industry.

\subsection{Heritage Tourism Marketing}

Heritage tourism marketing means convince and communicate with actual and potential tourists so as they pay visit to the heritage destination. Heritage tourism marketing is not really place marketing. There is a distinction between heritage tourism marketing and place marketing. In heritage tourism marketing the place or destination is not the only product rather the enriched past of the place is the main attraction. Improving service quality and visitors satisfaction is very important in heritage tourism marketing. Only advertisements and publicity in mass media and social networking sites is not enough for successful heritage tourism marketing. The marketer should try to provide an enriched experience to the tourists.

\subsection{Strengths}

\section{SWOT Analysis of Heritage Tourism Industry in Bangladesh}

1. Unique history and culture.

2. Significant architectural, historical and religious tourism products.

3. Cheap labor.

4. Three International and five domestic airports.

5. Accommodation facilities in different parts of the country. 


\subsection{Weaknesses}

1. Full potential of heritage tourism marketing is not realized.

2. Inadequate political support.

3. Lack of sufficient funding.

4. Lack of tourism marketing skills and experts.

5. Lack of investment in tourism marketing.

6. Lack of information and academic work about heritage tourism industry and the satisfaction of heritage tourists.

7. Lack of safety, security and hygienic in heritage sites.

8. Absence of heritage tourism marketing plan and public relations.

9. Small number of tour operators, insufficient national airlines and insignificant role of travel agent.

10. Lack of infrastructural development.

\subsection{Opportunities}

1. International recognition of the heritage sites.

2. Emerging interest of foreign tourists in heritage tourism.

3. Easy dissemination of information and access to important global communication media.

4. Unlocking economic potential of heritage tourism.

5. Diversification of tourism product portfolio.

\subsection{Threats}

1. Fierce competition in heritage tourism industry especially with neighboring countries.

2. Lack of synergy among stakeholders.

3. Lack of conservation effort of heritage sites.

4. Political instability in the country.

5. Image crisis of the country.

6. Improper implementation of tourism policy.

7. Lack of awareness among stakeholders about the potential of heritage tourism.

\section{Present Status of Heritage Tourism Marketing in Bangladesh}

The tourism marketing for heritage destinations in Bangladesh is mainly conducted by Bangladesh Parjatan Corporation and private tour operators. BPC takes participation in International tourism exhibitions in the world and tries to sell packages to tour operators and individual visitors. BPC also tries to inform the tourists all over the world about the heritage sites by their websites. But the website of BPC is not rich. Information provided about heritage destinations is not adequate and the pictures are not so attractive. Tourists will not get enough information about the accommodation and transport facilities from this website. BPC publishes advertisements in newspapers, magazines, television and radio but these advertisements cannot attract satisfactory number of tourists. BPC publishes advertisements in some specialized and special interest magazines to target some specific segments. The overall performance of BPC in tourism marketing is not satisfactory. Marketing initiatives of BPC are not well planned and creative. The manpower and technical expertise of BPC to formulate effective marketing policy and guideline is inadequate. There is no integration in the total marketing activities which is very essential to get a positive result.

Private tour operators do not spend sufficient amount of their fund for the promotional activities of heritage destinations. They do not conduct any well- planned promotional program for the heritage destinations. Their marketing activities is mainly based on traditional methods of marketing such as publishing advertisements in local newspapers, distributing brochures in Bengali and English language and providing some sales promotion. But there is no coordination and creativity in these marketing activities. Only a few of the tour operators use websites and the website contents are inadequate. Tourists from local and foreign countries will not get enough information from these websites. Most of the tour operators do not have separate marketing department or employee in charge of marketing. They suffer from a lack of fund to invest in marketing activities.

\subsection{Heritage tourism Products in Bangladesh}

Bangladesh is rich in historical and architectural wealth. There are many heritage destinations in this country that can attract both domestic and foreign tourists but lack of effective promotional program has made these heritage destinations less attractive than other sites of the world. There are many heritage sites of medieval period in Bangladesh which were established during Muslim and Pre- Muslim period. Language movement and 
war of independence also provides important heritage destinations to many tourists. Important heritage destinations of Bangladesh are as below:

\title{
3.1.1 Archaeological Tourism Products Lalbag Fort
}

The finest specimen of the Mughal period in Bangladesh is the Aurangabad Fort, also known as Lalbagh Fort. It occupies the south-western part of the Dhaka city, overlooking the Buriganga.. There are a small 3-domed mosque, the mausoleum of Bibi Pari, the reputed daughter of Nawab Shaista Khan and the Hammam and Audience Hall of the Governor. The main purpose of this fort was to provide a defensive enclosure of the palatial edifices of the interior and as such was a type of palace-fortress rather than a seizefort[14] (Lalbag Fort, 2014)

\begin{abstract}
Ahsan Manzil
Situated on the bank of the river Buriganga this stately monument was originally built in 1872 by Nawab Abdul Ghani, as a palace on the site of an old French Factory and it was named after his son Nawab Ahsanullah Bahadur.. Today Ahsan Manzil turned into a museum is a monument of immense historical value
\end{abstract} [15] (Ahsan Manzil, 2014)

\section{Sonargaon}

About $26 \mathrm{~km}$. from Dhaka, Sonargaon is the earliest known capital of Bengal. It was the seat of Deva Dynasty until the 13th century. From then onward till the advent of the Mughals, Sonargaon was the subsidiary capital of the Sultanate of Bengal. Among the ancient monuments still intact are the Tomb of Sultan Ghiasuddin (1399-1409 A.D.), the shrines of Panjpirs and Shah Abdul Alla and a beautiful mosque at Goaldi village[16] (Sonargaon, 2014)

\section{Wari Bateshwar}

Wari-Bateshwar is the site of an ancient fort city dating back to $450 \mathrm{BC}$ situated in the north-eastern part of Bangladesh. This 2500 years old site is a significant archaeological discovery. It challenges the earlier notions about the existence of early urban civilisation in Bangladesh. According to researchers, the discovery of artifacts and importantly the geographical location of Wari-Bateshawar indicate its Southeast Asiatic and Roman contacts[17] (Wari Bateshwar, 2014)

\section{Mainamati}

Mainamati once known as 'Samatata' denotes a land lying almost even with the sea-level. Salban Vihara situated it this site is an extensive centre of Buddhist culture of 7th to 12th century. Excavation on this heritage site has revealed over 50 ancient sites dotting the hills, mostly containing various types of Buddhist remains of the 8th to 12th centuries A. D. Excavations at a number of sites, exposing many Buddhist monasteries temples and stupas, have also yielded a rich collection of artifacts which eloquently speak of the glorious cultural attainments of the period[18] (Mainamati, 2014)

\section{Paharpur}

Paharpur Vihara is a treasured heritage of the world. It has been identified from a set of inscribed clay seals, as the reputed Somapura Vihara, of the great Pala emperor Dharmapala. It is the single largest Vihara south of the Himalayas. This immense quadrangular monastery has 177 monastic cells enclosing the courtyard and it is dominated by a lofty pyramidal temple in the centre. A site museum houses the representative collections of objects recovered from the area. The excavated finds have also been preserved at the Varendra Research Museum at Rajshahi.[19] (Paharpur, 2014)

\section{Mahasthangarh}

Mahasthangarh is the oldest archaeological site of Bangladesh which is situated on the western bank of the river Karatoa. The spectacular site is an imposing landmark in the region having a fortified area and its ancient ruins spread out within a semi circle of about $8 \mathrm{~km}$. radius. Several isolated mounds surround the fortified city. This 3rd century B. C. archaeological site is still held by the Hindus to be of great sanctity.

A visit to the site museum at Mahasthangarh will open up a wide variety of antiquities. Also noteworthy are the shrine of Shah Sultan Bulkhi Mahisawar and Gokul Medh in the neighbourhood of Mahasthangarh.[20] (Mahasthangarh, 2014) 


\section{Kantaji's temple}

This temple near Dinajpur town was built in 1752 by Maharaja Pran Nath of Dinajpur. Every inch of the temple surface is beautifully embellished with exquisite terracotta plaques, representing flora, fauna, geometric motifs, mythological scenes and an astonishing array of contemporary social scenes and favorite pastimes. The Maharaja's palace with relics of the past centuries and local museum are worth a visit. [21] (Kantaji's temple, 2014).

\section{Shait Gombudge Mosque, Bagerhat}

During the mid-15th century, a Muslim colony was founded near the sea coast- what is now known as the Bagerhat district by a saint named Ulugh Khan Jahan. Khan Jahan adorned his city with numerous mosques, tanks, roads, and other public buildings among those the most magnificent and the largest brick mosque in Bangladesh, is the Shait Gombudge mosque which means'60-domed Mosque'.[22] (Shait Gombudge Mosque, 2014)

\subsubsection{Religious Tourism Products}

Seven dome Mosque

Seven dome Mosque was made by Shaista Khan who was a Subadhar and army general of Mughal Empire in Bengal region from 1664 to 1688 . The mosque has a unique architectural value.

\section{Binat bibi Mosque}

Binat bibi mosque is a square, single domed mosque which was built more than 600 years ago. The mosque contains many Pre-Mughal features in its structure and design.

\section{Star Mosque}

Star Mosque, locally known as Tara Masjid is located in Armanitola area of the old part of Dhaka city. The mosque has ornate designs and is decorated with motifs of blue stars. It was built in the late 18th century by Mirza Golam Pir Mughal style by Mirza Ghulam in the late 18th century, this mosque was originally a simple rectangular mosque.

\section{Shrine of Hazrat Shah Paran}

'Shah Paran' (R) was a renowned Sufi saint who established a khanqah at Khadim Nagar about $7 \mathrm{~km}$ away from Sylhet town, where he started Sufi spiritual practices and activities. He was buried near his khanqah. For centuries, large numbers of devotees have been visiting his tomb, a practice which continues even today. Adjacent to the main tomb complex of Shah Paran there is another tomb visited by worshipers, that of Konya Shah.

\section{Shrine of Hazrat Shah Jalal}

The shrine of great Muslim Saint, Hazrat Shah Jalal (R.A.) is located at Dargah Mahalla in the heart of Sylhet town. This saint brought the message of Islam to the region in the early 14th century.

\section{The Dargah of Hazrat Shah Amanat} Chittagong.

The dargah Sharif of Hazrat Shah Sufi Amanat Shah lies to the central jail and east of the Laldighi,

\section{Other religious tourism products}

Other religious tourism products are the shrine of Sultan Bayezid Bostami, Choto Sona mosque Hussaini dalan, tomb of bibi Moriom Mughal Eid gah (Dhanmondi Eid gah) etc.

\section{1..3 Historical Tourism Products \\ Central Shahid Minar}

Symbol of Bengali nationalism, this monument was built to commemorate the martyrs' of the historic language movement on 21st February, 1952.

\section{Martyred Intellectual Memorial}

Martyred Intellectuals Memorial is a memorial built in memory of the martyred intellectuals of Bangladesh Liberation War. The memorial is located at Rayerbazar, Mohammadpur Thana in Dhaka. 


\section{National Poet's Grave}

Revolutionary poet Kazi Nazrul Islam died on 29th August 1976 and was buried here. The graveyard is adjacent to the Dhaka University Central Mosque.

\section{Bahadurshah Park}

Located at old city opposite the Jagannath University formerly Victoria Park this memorial place of 1857 was built to commemorate the martyr's of the first liberation war in the years of 1857-59 against British Rule.

\section{Curzon Hall}

In the wake of the first partition of Bengal in 1905 Curzon Hall was erected in Dhaka illustrating a happy blending of the Mughal and European tastes.

\section{Baldha Garden}

Established in 1904, by the late Narendra Narayan Roy, the garden is located in Wari ,Dhaka. This garden boasts a rich collection of indigenous and exotic plants.

\section{World War II Cemetery}

In this well-preserved cemetery, in Chittagong lie buried over 700 soldiers from Commonwealth countries and Japan, who died during the Second World War.

\section{Shilaidaha Kuthibari, Kushtia}

The beautiful mansion carries memory of nobel laureate poet Rabindranath Tagore (1861-1941) who made frequent visit to this place and used to stay here, in connection with administration of his Zamindari and enriched Bengali literature through his writtings during that time. It is located at a distance of about $20 \mathrm{~km}$. from Kushtia town.

\section{Other historical tourism Products}

There are some other notable historical tourism products in Bangladesh such as Suhrawardy Uddayan Old High Court Building Natore - Dighapatiya Rajbari (Palace) etc.

\section{Proposed Heritage Tourism Marketing Framework For Bangladesh}

The above heritage tourism marketing framework has been proposed for Bangladesh. At first a well coordinated planning group should be formed by tourism related government organizations (Bangladesh Parjatan Corporation, Bangladesh tourism board, Ministry of civil aviation and tourism), business community and other important stakeholders related to heritage tourism. Then this planning group should develop mission and vision of heritage tourism marketing in Bangladesh. Then a co-operative marketing plan should be developed which will guide the communication or promotional program. Marketing strategy will be developed that will provide direction to segment the heritage tourists and targeting appropriate segments. Relationship management program should be developed to ensure repeat visit and positive word of mouth influence. Heritage tourism information system will be developed that will contain important information about the tourists that will help to develop heritage tourists relationship management programs and developing marketing strategy development. Place marketing experts should play an important role here. 
Figure: Proposed Heritage Tourism Marketing Framework for Bangladesh

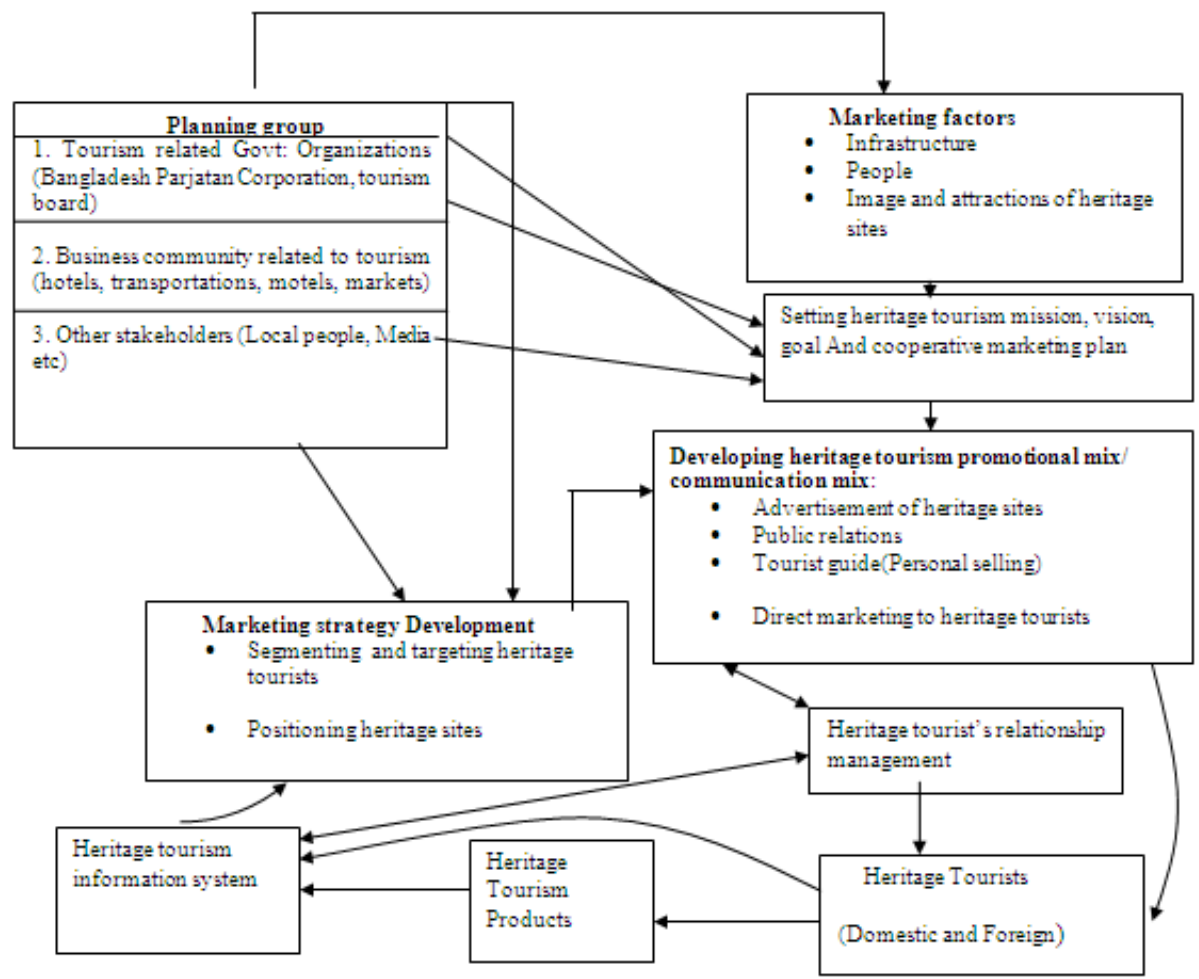

\section{Potential Impact of Heritage Tourism Marketing in Bangladesh}

A positive relationship exists between the funding of destination marketing and actual tourists receipts. Government with larger tourism promotion budgets also enjoy a higher level of International tourism spending. Heritage tourism marketing is also one form of destination marketing. There is an initial cost of marketing heritage destinations to attract tourists but well-designed marketing activities will generate visitation and spending in the economy of Bangladesh. Heritage tourism can create jobs, provide new business opportunities, protect heritage destinations and improve the quality of life of the local residents. Tourists will spend money directly in Bangladesh which will create positive multiplier effect in other sectors of the econopmy. When tourists make visit in various heritage destinations they will engage in other activities such as eating in hotels and restaurants and shopping in local markets. This will increase the earning of the business people in Bangladesh. Heritage tourism will provide employment opportunities to the young people of Bangladesh because tourism industry is labor intensive industry where young people can play a significant role. People will get both part-time and full time job opportunity in this industry. A well planned heritage tourism marketing program can improve the brand image of the entire country. Preservation of heritage attractions will be also encouraged by heritage tourism marketing because awareness of the people about the conservation of heritage places will be increased by promotional programs.

\section{Barriers of Heritage Tourism Marketing in Bangladesh}

1. Lack of skilled manpower is a major reason for the present status of improper heritage tourism marketing in Bangladesh. There is no academic or professional program to build skilled manpower in tourism marketing. Some universities and institutions provide graduation and diploma program for the students in tourism but these programs are inadequate to create destination marketing experts.

2. Tourism authority and tour operators of Bangladesh are suffering from serious lack of funding which act as a serious obstacle in the way of successful heritage tourism marketing.

3. The co-ordination of marketing activities among various parties such as tour operators, hotels and Bangladesh tourism board is on unsatisfactory level. Modern marketing strategies and long-term marketing plan for heritage destinations are absent in Bangladesh. Lack of networking among various stakeholders is a serious problem for successful heritage tourism marketing.

4. There are no national promotional initiatives for historical and archaeological sites in Bangladesh. Destination marketing expert is insufficient in our country.

5. There are also various marketing mix problems in heritage tourism marketing of Bangladesh which are no national promotion of heritage destinations, no national heritage product identification program, lack of 
well-known heritage destination brands. Tourism authority does not pay attention to the needs of heritage tourists. There is no initiative to conduct market research to know about the needs of heritage tourists.

6. The number of tourist information office is insufficient in heritage destinations for that reason tourist's face difficulties in the time of serious information need.

7. Transportation, security, food and shopping facilities are not satisfactory in heritage tourism marketing. Communication system with various historical sites is weak and access is difficult. There are many heritage regions without any airport and transportation system. This weak communication system has a negative effect in service quality of the tour operators. Food and shopping facility for the tourists are not adequate to crate satisfaction.

8. The conservation and protection system of heritage destinations is weak in our country which plays a negative role in marketing of these places.

\section{Recommendations}

The success of heritage tourism marketing in a country not only depends on government but also on private sector stakeholders. All of the stakeholders should play a different but coordinated role for successful heritage tourism marketing.

1. Promotion is critical for successful heritage tourism marketing. Traditional media such as TV, newspaper, radio, billboard can play an important role to promote heritage destinations. Brochures Posters, leaflets and information packages about heritage destinations and accompanying tourist's facilities should be produced and distributed to key areas such as hotels, airports and foreign embassies. Emphasis should be given on Internet marketing because this is a cost effective way to attract both domestic and foreign tourists. Websites of tourism related Government organizations and private tour operators should be interactive and rich with photos, videos and articles on historical and archaeological places. Social media marketing tools such as Facebook and Twitter should be used with other traditional medias. Direct marketing tools have become successful in some European countries to promote heritage destinations so Bangladesh can also use these tools.

2. Key for improving heritage tourism marketing is effective protection and conservation of historic and archaeological resources. By actively identifying and registering heritage places at local level and international level especially with World Heritage Organization some level of preservation and protection of these historic resources can be ensured. Conservation club should be formed for important heritage places so that protection will be ensured.

3. Well trained tour guides who can interpret heritage destinations in a creative and exciting way are needed for creating a successful tourism experience. These guides can play the role of salesperson for heritage destinations of Bangladesh.

4. Providing quality service to the tourists is an important part of heritage marketing. Therefore, the adequate safety and security of the tourists should be ensured to remove negative image. Tourism facilities and services like accommodation, food and beverage, entertainments, travel agents, tour operations, shopping malls, supermarkets, transporters have to be established in good number in international standard for heritage places by public and private sectors.

5. Unexplored heritage destinations must be taken into consideration to be explored properly and established all tourist facilities there for the sake of the development of tourism. They must be promoted and more research should be conducted in this places.

6. To make every marketing project successful all the relevant stakeholders of heritage tourism should be involved in the process of developing and implementing marketing programs. Heritage officers should think positively about the use of marketing concepts in heritage destinations and undertake marketing plan cautiously. Government should play the role of central co-coordinator to link all relevant stakeholders. Representatives from local residents should be taken into every marketing project because they have knowledge about the site. Tour operators and tourism related business owners should try to create new experience.

7. Both the Government and the private sector investment are quite insufficient for heritage tourism marketing in Bangladesh. So fund should be raised and efficient use of this fund should be ensured with the help of tourism marketing experts.

8. To implement successful heritage tourism marketing plan expert on destination marketing and professional marketing people should be appointed. Academic research on tourism marketing should be encouraged. Universities should give emphasis on tourism marketing as a separate discipline. 


\section{Conclusion}

Bangladesh with it's rich history and culture has all the potential and ingredients of heritage tourism development. Heritage tourism can make a significant contribution in the economy of Bangladesh. Wellplanned and effective tourism marketing plan for heritage destinations is essential to attract sufficient number of tourists. However successful heritage tourism marketing cannot take place by itself. It needs coordination among all the relevant stakeholders, creative promotional program and infrastructural development. Tourist's facilities such as food, shopping, transporatation etc. should be developed to meet the basic needs of the tourists. And above all, both private and public sectors should come forward and join their hands to make heritage tourism marketing successful in Bangladesh.

\section{References}

[1]. Understanding tourism: basic glossary. (2014). Retrieved from http://media.unwto.org/content/understanding-tourism-basicglossary

[2]. Ghosh, B. 2001. Tourism and Travel Management( New Delhi: Vikas Publishing House Pvt. Ltd).

[3]. Dabour, N. ( 2003) Problems and Prospects of Sustainable Tourism Development In The OIC Countries: Eco- Tourism. Journal of Economic Cooperation vol 24. P- 25-62.

[4]. Malaysia Tourism Promotion Board. (2004). Profile of Tourists by Selected Market 2004. Planning and Research Division, Tourism Malaysia, Kuala Lumpur.

[5]. Shamsuddoha, M. (2008) sustainability of Tourism industry: Bangladesh Perspective. http:// ssrn.com/ abstract= 1314779( Electronically accessed at $8^{\text {th }}$ February 2012).

[6]. Ali, M.M. and Parvin, R. "Strategic management of Tourism sector in Bangladesh to raise gross domestic product". Business and Economics Working Paper series. AIUB-BUS-ECON- 2010-04, 1-15.

[7]. Weiermair K., \& Mathies C. 2004. The Tourism and Leisure Industry- shaping the future (New York: The Heiworth Hospitality Press).

[8]. Edgell, D. 2006. "Managing sustainable tourism. A legacy for the future (Binghamton: New York: The Haworth Press, Inc., 10 Alice Street).

[9]. Ahmed, I. "A Participatory Approach To Conservation: Working With The community To Save The cultural Heritage Of Panamnagar". BRAC University Journal, Vol 3, 25-33

[10]. National Trust for Historic Preservation. (2008). Heritage tourism. www.nationaltrust.org/heritage_tourism.

[11]. Hargrove, Cheryl M. 2002. Heritage Tourism. Cultural Resource Management. Issue 25-1.Getting Started: How to Succeed in Heritage Tourism. 1993. National Trust for Historic Preservation in the United States.

[12]. Silberberg, T. 1995. Cultural tourism and business opportunities for museums and heritage sites. Tourism Management, $16(5): 361-365$

[13]. Gitera, |N. (2008) "The Development and Promotion Of Heritage Tourism In Rwanda", Masters Thesis, Cape Peninsula University Of Technology.

[14]. Lalbagh Fort. (2014). from http://www.parjatan.gov.bd/index.php/en/component/tourism/?view=page\&layout=sub sub menu\&sub sub menu id=26\&Itemid $=102$

[15]. Ahsan Manzil. (2014). Retrieved from http://www.parjatan.gov.bd/index.php/en/component/tourism/?view=page\&layout=sub_sub_menu\&sub_sub_menu_id=28\&Itemid $=102$

[16]. Sonargaon.(2014). Retrieved from http://www.parjatan.gov.bd/index.php/en/component/tourism/?view=page\&layout=sub_sub_menu\&sub_sub_menu_id=27\&Itemid $=102$

[17]. War Bateshwar (2014). Retrieved from http://www.parjatan.gov.bd/index.php/en/component/tourism/?view=page\&layout=sub_sub_menu\&sub_sub_menu_id=20\&Itemid $=102$ http://www.parjatan.gov.bd/index.php/en/component/tourism/?view=page\&layout=sub_sub_menu\&sub_sub_menu_id=23\&Itemid $=102$

[19]. Paharpur.(2014). Retrieved from http://www.parjatan.gov.bd/index.php?option=com_tourism\&view=page\&layout=sub_sub_menu\&sub_sub_menu_id=22\&Itemid= 102

[20]. Mahasthangarh _.(2014). Retrieved from http://www.parjatan.gov.bd/index.php/en/component/tourism/?view=page\&layout=sub_sub_menu\&sub_sub_menu_id=21\&Itemid $=102$

[21]. Kantaji's temple.(2014). from http://www.parjatan.gov.bd/index.php/en/component/tourism/?view=page\&layout=sub_sub_menu\&sub_sub_menu_id=25\&Itemid $=102$

[22]. Shait Gombudge Mosque. (2014). Retrieved from http://www.parjatan.gov.bd/index.php/en/component/tourism/?view=page\&layout=sub_sub_menu\&sub_sub_menu_id=24\&Itemid $=102$ 